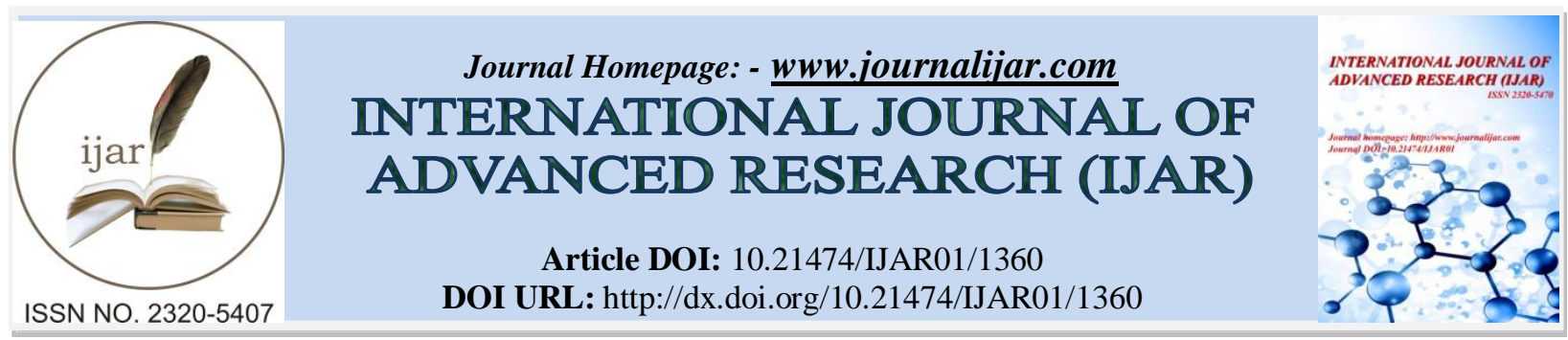

RESEARCH ARTICLE

\title{
EFFECTIVE TRAINING PROGRAMMES AND ITS IMPACT ON EMPLOYEE.
}

\section{Dr. M. Usha ${ }^{1}$, Dr. M. Nandhini ${ }^{1}$ and Dr. P. Palanivelu ${ }^{2}$.}

1. Assistant Professor, Department of Management (UG) Karpagam University Coimbatore-21

2. Professor \& Controller of Examinations Department of Management Studies \&Research, Karpagam University, Coimbatore-21

\section{Manuscript Info}

Manuscript History

Received: 16 June 2016

Final Accepted: 19 July 2016

Published: August 2016

Key words:-

*S = Spark Industries Pvt Ltd., * S.S $=$ S.S.A Castings India Pvt Ltd., * SP = SPB Alloys Steel Pvt Ltd., * $\mathrm{SE}=$ Senkar Industries Pvt Ltd., $* \mathrm{E}=$ Everon Castings Pvt Ltd., NSDC National Skill Development Corporation

\section{Abstract}

The study is about the impact of effective training programme provided to employees. Employees are major assets of any organization. The active role they play towards a company's success cannot be underestimated. As a result, equipping these unique assets through effective training becomes imperative in order to maximize the job performance. Investing in employee training should improve employee retention rates, job satisfaction and creativity for new product ideas. Well-trained workers help to increase productivity and profits. Training and development are often used to close the gap between current performances and expected future performance.

In the real world, organizational growth and development is affected by a number of factors. In light with the present research during the development of organizations, employee training plays a vital role in improving performance as well as increasing productivity. This in turn leads to placing organizations in the better positions to face competition and stay at the top.

Copy Right, IJAR, 2016,. All rights reserved.

\section{Introduction:-}

Companies need to be aware of face more realistically towards keeping their human resources up-to date. In so doing, managers need to pay special attention to all the core functions of human resource management as this plays an important role in different organizational, social and economically related areas among others that are influential to the attainment of the company goals and thus company successful continuation in the market. This study, therefore, goes on to discuss one of the core functions of human resource which is training.

Training can help to solve these performance problems by explaining the details of the job. This should reduce duplication of effort in the workplace, the time spent correcting mistakes. Job satisfaction generally increases and self-esteem improves when employees better understand the workings of the company. Training can also enhance morale on the job and loyalty to the company. Workers who believe their company offers excellent training opportunities are generally less likely to leave their companies.

\section{About the engineering industries:-}

The engineering sector is one of the largest sectors among the industrial segments in India. Majorly comprising heavy and light engineering segments, this industry is closely linked with the manufacturing segments of the 
economy. Engineering industry manufactures a wide range of products, with heavy engineering goods accounting for bulk of the production. Most of the leading players produce high-value heavy engineering goods using high-end technology. The major end-user industries for heavy engineering goods are power, infrastructure, steel, cement, petrochemicals, oil and gas, refineries, fertilizers, mining, railways, automobiles, and textiles.

Consequently, the small and unorganized firms have small market presence. The unorganized sector specializes in manufacturing low-technology products and a few small-scale units are involved only in assembly of imported components. Light engineering goods are essentially used as inputs by the heavy engineering industry. On the other hand, light engineering goods manufacturers use medium to low-end technology. The entry barrier is low owing to relatively lower requirement of capital and technology.

This segment is characterized by dominance of small and unorganized players, however, a few medium and large scale firms produce high value-added products. This segment is also characterized by small capacities and high level of competition.

Coimbatore is the second largest city in the South Indian state of Tamil Nadu. It is the administrative headquarters of the Coimbatore District and a major textile and engineering hub of South India. It is referred to as "the Manchester of South India. Industry Growth Prospects in the Coimbatore engineering sector showed immense optimism in the growth prospects of the sector.

\section{Statement of the problem:-}

1. What are the expectations of the employees regarding the training programmes adopted by the employer? 2 . What do the employees perceive about the training programes? 3. Does the employees satisfy towards the training programme? 4. What are the different types of training that are adopted by the companies to influence their employee to enhance their productivity? 5. What is the most dominant factor that influences the employees to enhance the morale and productivity?

\section{Prior empirical study report:-}

Researchers argue that the recognition of the importance of training in recent years has been heavily influenced by the intensification of competition and the relative success of organizations where investment in employee development is considerably emphasized (Ceardwell et al. 2013). Related to the above, Eeardinel et al. (2014) add that technological developments and organizational change have gradually led some employers to the realization that success relies on the skills and abilities of their employees, thus a need for considerable and continuous investment in training and development. According to Swart et al., (2015), bridging the performance gap refers to implementing a relevant training intervention for the sake of developing particular skills and abilities of the employees and enhancing employee performance. He further elaborate the concept by stating that training facilitate organization to recognize that its workers are not performing well and a thus their knowledge, skills and attitudes needs to be molded according to the firm needs.

\section{Research gap:-}

According to the report of NSDC, India needs to train engineering industries manpower alone with the cooperation of the employers to cater to the higher employment demand from the engineering industry expected USD from 165 to 175 billion by 2022 .

\section{Objective of the study:-}

- To identify the Training Programmes adopted in the companies

- To examine the morale of the employee in the companies

- To access the satisfaction level of the employee in the companies

\section{Research Methodology:-}

Facts, information or premises systematically collected and formally presented for the purpose of drawing interference, a methodology includes sources of data, collection of data and analysis of data. It seems appropriate at this juncture to explain the difference between research methods and Research Methodology. Research methods may be understood as all those techniques that are used for conduction of Research. Research methodology is a way to systematically solve the research problem. Descriptive Research Design has been used in this research work. Five 
industries were selected for the study namely Spark Laser Industries, S.S.A Castings India Pvt Ltd, SPB Alloys Steel Pvt Ltd., Senkar Industries., Everon Castings Pvt Ltd., The sample size is 250, data were collected from 250 employees, to analyze the impact of training progrommes. Simple random sampling is used to select the sample.

\section{Statistical analysis and interpretations:-}

* Simple percentage analysis * Chi-square Analysis *Analysis of Variance

Hypothesis of the study:-

According to this model there is five independent and two dependent variable this model is used for the research.

On the job Training Method:-

\begin{tabular}{|l|l|l|}
\hline Instructor-Led Training & $\begin{array}{l}\text { Impact of } \\
\text { Training and } \\
\text { Development }\end{array}$ \\
\hline Hands-On Training & $\begin{array}{l}\text { Morale of } \\
\text { Employee }\end{array}$ \\
\hline E-Learning & & \\
\hline
\end{tabular}

\section{Data analysis:-}

Percentage analysis :-

Data were collected from the respondents of the Engineering industries. To enable analysis, data were classified on the basis of their opinion given on various aspects and a percentage analysis was done.

Table 1:- Table showing the gender wise classification.

\begin{tabular}{|c|c|c|c|c|c|}
\hline \multirow{2}{*}{ INDUSTRIES } & \multicolumn{2}{|c|}{ MALE } & \multicolumn{2}{c|}{ FEMALE } & TOTAL \\
\cline { 2 - 6 } & $\begin{array}{c}\text { No of } \\
\text { Respondence }\end{array}$ & Percentage & $\begin{array}{c}\text { No of } \\
\text { Respondence }\end{array}$ & Percentage & \\
\hline Spark Industries Pvt Ltd., & 35 & 70 & 15 & 30 & 50 \\
\hline S.S.A Castings India Pvt Ltd., & 41 & 82 & 9 & 18 & 50 \\
\hline SPB Alloys Steel Pvt Ltd., & 43 & 86 & 7 & 14 & 50 \\
\hline Senkar Industries Pvt Ltd., & 41 & 82 & 9 & 18 & 50 \\
\hline Everon Castings Pvt Ltd., & 50 & 100 & Nil & Nil & 50 \\
\hline Total & 210 & & 40 & & 250 \\
\hline
\end{tabular}

The above table reveals the gender wise classification among 250 respondence in five industries. In Spark Industries Pvt Ltd.,70 percentage of the respondents were male and 30 percentage of them were female, as like that, S.S.A Castings India Pvt Ltd., and Senkar Industries Pvt Ltd.,, 82 percentage of the respondents were male and 9 percentage of them were female,. In SPB Alloys Steel Pvt Ltd.,, 86 percentage of them were male and 7 percentage of them were female and in Everon Castings Pvt Ltd.,, 100 percentage of them were male. 
Table 3:- Table showing the satisfaction level of employees.

\begin{tabular}{|c|c|c|c|c|c|c|c|c|c|c|c|c|c|c|c|c|c|c|c|c|c|c|c|c|c|}
\hline \multirow[t]{2}{*}{$\begin{array}{l}\text { Partic } \\
\text { ulars }\end{array}$} & \multicolumn{5}{|c|}{ Highly Satisified } & \multicolumn{5}{|c|}{ Satisified } & \multicolumn{5}{|c|}{ Neutral } & \multicolumn{5}{|c|}{ Dissatisified } & \multicolumn{5}{|c|}{$\begin{array}{c}\text { Highly } \\
\text { Dissatisified }\end{array}$} \\
\hline & $S$ & $\begin{array}{l}\text { S. } \\
\text { S }\end{array}$ & $\begin{array}{l}\mathrm{S} \\
\mathrm{P}\end{array}$ & $\begin{array}{l}\mathrm{S} \\
\mathrm{E}\end{array}$ & $\mathrm{E}$ & $\mathrm{S}$ & $\begin{array}{l}\text { S. } \\
\text { S }\end{array}$ & $\begin{array}{l}\mathrm{S} \\
\mathrm{P}\end{array}$ & $\begin{array}{l}\mathrm{S} \\
\mathrm{E}\end{array}$ & $\mathrm{E}$ & $\mathrm{S}$ & $\begin{array}{l}\text { S. } \\
\text { S }\end{array}$ & $\begin{array}{l}\mathrm{S} \\
\mathrm{P}\end{array}$ & $\begin{array}{l}\mathrm{S} \\
\mathrm{E}\end{array}$ & $\mathrm{E}$ & $\mathrm{S}$ & $\begin{array}{l}\text { S. } \\
\text { S }\end{array}$ & $\begin{array}{l}\mathrm{S} \\
\mathrm{P}\end{array}$ & $\begin{array}{l}\mathrm{S} \\
\mathrm{E}\end{array}$ & $\mathrm{E}$ & $\mathrm{S}$ & $\begin{array}{l}\mathrm{S} . \\
\mathrm{S}\end{array}$ & $\begin{array}{l}\mathrm{S} \\
\mathrm{P}\end{array}$ & $\begin{array}{l}S \\
E\end{array}$ & $\mathrm{E}$ \\
\hline $\begin{array}{l}\text { Instruct } \\
\text { or-Led } \\
\text { Trainin } \\
\mathrm{g}\end{array}$ & $\begin{array}{l}1 \\
3\end{array}$ & $\begin{array}{l}1 \\
2\end{array}$ & $\begin{array}{l}1 \\
1\end{array}$ & $\begin{array}{l}1 \\
8\end{array}$ & $\begin{array}{l}1 \\
5\end{array}$ & $\begin{array}{l}2 \\
0\end{array}$ & $\begin{array}{l}2 \\
2\end{array}$ & $\begin{array}{l}2 \\
1\end{array}$ & $\begin{array}{l}2 \\
6\end{array}$ & $\begin{array}{l}2 \\
3\end{array}$ & $\begin{array}{l}1 \\
2\end{array}$ & $\begin{array}{l}1 \\
0\end{array}$ & $\begin{array}{l}1 \\
3\end{array}$ & 4 & 8 & 5 & 2 & 3 & 2 & 2 & - & - & 2 & - & 2 \\
\hline $\begin{array}{l}\text { Interact } \\
\text { ive } \\
\text { Metho } \\
\text { ds }\end{array}$ & $\begin{array}{l}1 \\
6\end{array}$ & $\begin{array}{l}1 \\
9\end{array}$ & $\begin{array}{l}1 \\
2\end{array}$ & $\begin{array}{l}1 \\
1\end{array}$ & $\begin{array}{l}1 \\
3\end{array}$ & $\begin{array}{l}2 \\
4\end{array}$ & $\begin{array}{l}2 \\
7\end{array}$ & $\begin{array}{l}2 \\
1\end{array}$ & $\begin{array}{l}2 \\
3\end{array}$ & $\begin{array}{l}2 \\
3\end{array}$ & 8 & 4 & $\begin{array}{l}1 \\
4\end{array}$ & $\begin{array}{l}1 \\
3\end{array}$ & 9 & 2 & - & 3 & 3 & 5 & - & - & - & - & - \\
\hline $\begin{array}{l}\text { Hands- } \\
\text { On } \\
\text { Trainin } \\
\text { g }\end{array}$ & $\begin{array}{l}1 \\
0\end{array}$ & $\begin{array}{l}1 \\
1\end{array}$ & $\begin{array}{l}1 \\
4\end{array}$ & 9 & $\begin{array}{l}1 \\
3\end{array}$ & $\begin{array}{l}2 \\
3\end{array}$ & $\begin{array}{l}2 \\
0\end{array}$ & $\begin{array}{l}2 \\
4\end{array}$ & $\begin{array}{l}3 \\
1\end{array}$ & $\begin{array}{l}2 \\
6\end{array}$ & $\begin{array}{l}1 \\
0\end{array}$ & $\begin{array}{l}1 \\
0\end{array}$ & $\begin{array}{l}1 \\
1\end{array}$ & 8 & 9 & 4 & 6 & 4 & 2 & 2 & 3 & 3 & - & - & - \\
\hline $\begin{array}{l}\text { Compu } \\
\text { ter- } \\
\text { Based } \\
\text { Trainin } \\
\text { g }\end{array}$ & 8 & $\begin{array}{l}1 \\
0\end{array}$ & $\begin{array}{l}1 \\
2\end{array}$ & $\begin{array}{l}1 \\
4\end{array}$ & $\begin{array}{l}1 \\
5\end{array}$ & $\begin{array}{l}2 \\
8\end{array}$ & $\begin{array}{l}2 \\
5\end{array}$ & $\begin{array}{l}2 \\
4\end{array}$ & $\begin{array}{l}3 \\
0\end{array}$ & $\begin{array}{l}2 \\
5\end{array}$ & $\begin{array}{l}1 \\
2\end{array}$ & $\begin{array}{l}1 \\
5\end{array}$ & 8 & 6 & 8 & 2 & 5 & 4 & - & 2 & - & 6 & 2 & - & 4 \\
\hline $\begin{array}{l}\text { E- } \\
\text { Learni } \\
\text { ng }\end{array}$ & $\begin{array}{l}1 \\
2 \\
\end{array}$ & $\begin{array}{l}2 \\
0\end{array}$ & $\begin{array}{l}1 \\
5\end{array}$ & $\begin{array}{l}1 \\
0\end{array}$ & $\begin{array}{l}1 \\
3 \\
\end{array}$ & $\begin{array}{l}1 \\
2 \\
\end{array}$ & $\begin{array}{l}2 \\
5\end{array}$ & $\begin{array}{l}2 \\
8 \\
\end{array}$ & $\begin{array}{l}2 \\
8\end{array}$ & $\begin{array}{l}2 \\
2 \\
\end{array}$ & $\begin{array}{l}1 \\
6 \\
\end{array}$ & 5 & 7 & 9 & 7 & 6 & - & - & 2 & 6 & - & - & - & - & 2 \\
\hline $\begin{array}{l}* \mathbf{S} \\
* \mathbf{S P}\end{array}$ & $\mathbf{S}_{\mathbf{C}}$ & & & & $\mathbf{S P}$ & 7 & & $\begin{array}{l}* \mathrm{~S} \\
* \mathrm{~S}\end{array}$ & & S. & & $x$ & & & $\mathbf{0}$ & $\mathbf{I}$ & & & & & & & & & \\
\hline
\end{tabular}

The above table reveals the level of satisfaction of employees towards the adopted training programme. Most of the respondents were satisfied towards the provided training programme. 
Table 5:- Table showing the morale of the employees towards the adopted training programmes.

\begin{tabular}{|c|c|c|c|c|c|c|c|c|c|c|c|c|c|c|c|c|c|c|c|c|}
\hline \multirow[t]{2}{*}{ Particulars } & \multicolumn{5}{|c|}{ Strongly agree } & \multicolumn{5}{|c|}{ Agree } & \multicolumn{5}{|c|}{ Disagree } & \multicolumn{5}{|c|}{ Strongly Disagree } \\
\hline & $\mathrm{S}$ & $\begin{array}{l}\mathrm{S} . \\
\mathrm{S}\end{array}$ & SP & SE & $\mathrm{E}$ & $\mathrm{S}$ & S.S & SP & $\mathrm{SE}$ & $\mathrm{E}$ & $\mathrm{S}$ & $\begin{array}{l}\mathrm{S} . \\
\mathrm{S}\end{array}$ & $\mathrm{SP}$ & SE & $\mathrm{E}$ & $\mathrm{S}$ & $\begin{array}{l}\mathrm{S} . \\
\mathrm{S}\end{array}$ & SP & $\begin{array}{l}S \\
E\end{array}$ & $\mathrm{E}$ \\
\hline $\begin{array}{l}\text { Good Moral } \\
\text { of } \\
\text { Employees }\end{array}$ & 15 & 10 & 18 & 13 & 17 & 28 & 30 & 32 & 27 & 33 & 7 & 10 & - & 5 & 4 & - & - & - & 5 & - \\
\hline $\begin{array}{l}\text { Work } \\
\text { efficiency } \\
\text { increased }\end{array}$ & 20 & 10 & 23 & 20 & 10 & 30 & 32 & 25 & 20 & 30 & - & 8 & 2 & 10 & 5 & - & - & - & - & 5 \\
\hline $\begin{array}{l}\text { Co- } \\
\text { ordination } \\
\text { with team } \\
\text { enhanced }\end{array}$ & 18 & 12 & 13 & 16 & 19 & 22 & 32 & 27 & 34 & 31 & $\begin{array}{l}1 \\
0\end{array}$ & 6 & 5 & - & - & - & - & 5 & - & - \\
\hline $\begin{array}{l}\text { Creates } \\
\text { interest in } \\
\text { taking Risk } \\
\text { work }\end{array}$ & 22 & 12 & 12 & 14 & 20 & 28 & 30 & 38 & 26 & 30 & - & 8 & - & 6 & - & - & - & - & 4 & - \\
\hline $\begin{array}{l}\text { Voluntary } \\
\text { involvement }\end{array}$ & 19 & 15 & 12 & 11 & 16 & 31 & 35 & 32 & 39 & 32 & - & - & 6 & - & 2 & - & - & - & - & - \\
\hline $\begin{array}{lr}* \mathbf{S} & =\mathbf{S p a} \\
* \mathbf{S P} & =\mathbf{S I} \\
* \mathbf{E} & =\mathbf{E}\end{array}$ & 0 & as & gs & $\mathbf{L}$ & $*$ & & $\begin{array}{l}\text { S.S } \\
\text { Sen }\end{array}$ & 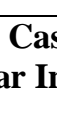 & 10 & 10 & 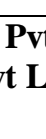 & $\begin{array}{l}\text { Ltd } \\
\text { d., }\end{array}$ & & & & & & & & \\
\hline
\end{tabular}

The above table reveals the morale of the employees towards the adopted training programmes Most of the respondents were agree towards the provided training programme that it enhances the their moral, work efficiency, coordination, interest in taking risk and also encourages for the voluntary involvement.

Table 6:- Table Showing chi-square Analysis

\begin{tabular}{|l|c|c|c|c|}
\hline \multicolumn{1}{|c|}{ Null hypothesis } & $\begin{array}{c}\text { Degree of } \\
\text { freedom }\end{array}$ & Calculated value & $\begin{array}{c}\text { Table value } \\
\text { Significant/Not } \\
\text { significant }\end{array}$ & Not Significant \\
\hline $\begin{array}{l}\text { There is no significant relationship } \\
\text { between experience and adopted training } \\
\text { programmes }\end{array}$ & 16 & 35.23 & 21.59 & 21.02 \\
\hline $\begin{array}{l}\text { There is no significant relationship } \\
\text { between age and training programmes }\end{array}$ & 12 & 17.87 & Significant \\
\hline
\end{tabular}

\section{Analysis of variance:-}

Table 7:- Table showing Analysis of Variance.

\begin{tabular}{|c|c|c|c|c|c|c|}
\hline $\begin{array}{l}\text { Source of } \\
\text { Variation } \\
\end{array}$ & Sum of Squares & $\begin{array}{c}\text { Degrees of } \\
\text { Freedom }\end{array}$ & $\begin{array}{c}\text { Mean Sum of } \\
\text { Square } \\
\end{array}$ & F Value & p Value & $\begin{array}{c}\text { Significant / Not } \\
\text { Significant }\end{array}$ \\
\hline $\begin{array}{l}\text { Between } \\
\text { Groups }\end{array}$ & 142.99 & 3 & 47.66 & 1.48 & .07 & NS \\
\hline $\begin{array}{l}\text { Within } \\
\text { Groups }\end{array}$ & 128.01 & 4 & 32.00 & & & \\
\hline Total & 271 & & & & & \\
\hline & & & & & & \\
\hline
\end{tabular}

$\mathrm{S}$ - Significant ( $\mathrm{p}$ Value $\leq 0.05) ; \mathrm{NS}-$ Not Significant (p Value $>0.05$ ) 


\section{Findings:-}

The Finding of the study is summarized as below:

* The study reveals that among 250 respondents, 80 percent of the respondents are male workers and 20 percent of them are female. It is thus obvious that a large percent of the sample respondents are male.

* 18 percentage of them influenced by good Instructor-Led Training, 40 percentage of the respondents were influenced by the Interactive Methods, 20 percentage of them attracted towards Hands-On Training, 20 percentage of them influenced, due to Computer-Based Training and the 14 percentage of them because of ELearning.

* Most of the respondents were agree towards the provided training programme that it enhances the their moral, work efficiency, coordination, interest in taking risk and also encourages for the voluntary involvement.

* Most of the employees are satisfied towards the adopted training programmes

- 40 percent of the respondents were under 11-10 years of experience and 10 percent of the respondents were below 5 years of experience, who were retained in the industry towards the adopted training programmes.

* Employees agree that the adopted training programme motivating them to be with good moral, bringing coordination, increasing work efficiency, making them to involve voluntary and also creating interest in taking risk in their work.

\section{Suggestions:-}

Some valuable suggestions are recommended to improve the training programmes in Engineering industry, and the company may utilize the suggestions for its policy implications to run it smoothly. It leads to increase the efficiency of the company's.

1. The companies are concentrating more on compensation strategies to train the employee, it can be concentrated some more with taking advantage of real-life learning opportunities in the workplace.

2. Key learning aspect has to be highlighted to the employees in the training.

3. Ongoing feedback has to be welcomed, it is done in specific intervals.

4. The experienced employee can be credited with some more facilities beyond presently adopted training programmes. Which influence and to encourage them and also for a good industrial relation.

\section{Conclusion:-}

Training Programmes adopted in engineering industry represents satisfaction to the employees, but business problems are uncertain, and change is one factor which doesn't change. Management would be always aware of finding the true reason as to why an employee is not satisfied towards the job or organization and should take necessary measures to rectify through the training programmes. In this study E-learning method of training has to be concentrated to enhance the employee satisfaction and morale. Training programmes should be adopted according to the employees, type of organization and the nature of the organization is essential for optioning job satisfied and to get the productivity from the skilled employees.

\section{References:-}

1. Ceardwell, Haru, \& Hashim, M. (2013)."A Guide to Human Resource Management: Basic concepts". Academic Press Corporation, Salk lake city, United State.

2. Eeardinel, Ceni \& Gilley, J., England, S. and Wesley, A. (2013). Principles of Human Resource Management. Perseus Publishing.

3. Swart \& Cutler, G. (2012). Internet summons Pete to jump ship. Research Technology Management

4. Prasad, C.S., (2004) Small and Medium Enterprises in Global Perspective, Employment Generation and WTO. Vision 2012, New Century Publications, New Delhi,

5. Sharma, A.K., (2006) Labour Economics, Anmol Publications Pvt. Ltd., New Delhi, 2006.

6. Sai, P.C., (2014) "Employment Trends", HRD Times, Vol.9, No. 8, Aug, pp.27-28.

7. Kothari C.R, Research Methodology Methods and Techniques, Tata Mc Graw hill Publishers, New Delhi, Fifth Edition, (2012).

\section{Websites referred:-}

1. www.labourfount.com

2. www.ciionline.org

3. www.labour.nic.in

4. www.empreten.com

5. www.nsic.com 